\title{
Developing ethyl formate treatment for disinfesting pipfruit
}

\author{
L.E. Jamieson, M.J. Griffin, N.E.M. Page-Weir, A. Chhagan, S.P. Redpath \\ and P.G. Connolly \\ The New Zealand Institute for Plant E Food Research Limited (Plant E Food Research), \\ Private Bag 92169, Auckland \\ Corresponding author: Lisa.Jamieson@plantandfood.co.nz
}

\begin{abstract}
Mealybugs, scale insects, thrips and apple leafcurling midge (ALCM) on packed New Zealand apples are a concern for export markets, and there is interest in 'soft' technologies to remove insects in postharvest treatments. Ethyl formate (EF) is a Generally Recognised As Safe (GRAS) plant volatile compound, which was used in trials to reduce pest incidence on apples to acceptable rates for export markets. A treatment of $0.3 \% \mathrm{EF}$ $\left(+\mathrm{CO}_{2}\right)$ for $1 \mathrm{~h}$ controlled $99 \%$ of onion thrips and latania scale, and $0.81 \% \mathrm{EF}\left(+\mathrm{CO}_{2}\right)$ for $1 \mathrm{~h}$ controlled obscure mealybug. Treatment concentrations and times required to control ALCM (4.94\% EF for $4 \mathrm{~h}$ ) was beyond the apple quality tolerance level. Further research is required to determine apple quality tolerance levels, other market access pest EF concentration mortality responses, sorption rates of different apple cultivars and effect of temperature on pest mortality and fruit responses.
\end{abstract}

Keywords disinfestation, pest control, postharvest, Thrips tabaci, Hemiberlesia lataniae, Pseudococcus viburni, Dasineura mali, Quadraspidiotus perniciosus, ethyl formate, carbon dioxide.

\section{INTRODUCTION}

The presence of arthropods, such as mealybugs, scale, thrips and apple leafcurling midge, on packed New Zealand apples is a concern for many export markets (e.g. Asia, Australia, USA). The continuing loss of chemicals (e.g. organophosphates and methyl bromide) for insect and mite control has increased commercial interest in other soft technologies that allow greater market access for pipfruit.

The New Zealand pipfruit industry has successfully developed and implemented high pressure washing (HPW) systems, in export packhouses (D.J. Rogers \& A.B Woolf, Plant \& Food Research, unpublished data). Although
HPW removed $>90 \%$ of most pests, further risk mitigation is required for reliable market access. Currently the pipfruit sector is funding research on hot water/ultraviolet-C-wavelength (UV-C) and ethyl formate fumigation to be used along with HPW and field control measures to provide a systems approach for controlling a range of pests.

Ethyl formate (EF) is a Generally Recognised As Safe (GRAS) compound considered safe for use with human food (US FDA 2006; Anonymous 1993), and is available in New Zealand under the trade name Vapormate ${ }^{\mathrm{TM}}$ (16.7 wt\% EF dissolved in liquid $\mathrm{CO}_{2}$ ). EF breaks down into formic acid and ethanol and is exempt from Maximum 
Residue Limits (MRL) for use as a postharvest treatment on plant products (MPI 2013). EF is effective against a range of pests on a range of commodities (Simpson et al. 2004, 2007; van Epenhuijsen et al. 2007; De Lima 2009, 2010; Chhagan et al. 2013; Griffin et al. 2013; Jamieson et al. 2013; Pupin et al. 2013).

Results from a feasibility trial investigating the efficacy of ultra low oxygen (ULO) combined with ethyl formate (EF) or ethyl acetate (both applied at $0.5^{\circ} \mathrm{C}$ ) showed that $\mathrm{EF}$ in particular had potential to control surface pests on apples while internal pests, e.g. codling moth larvae, were more tolerant to this treatment (Jamieson et al. 2013).

This study aimed to rank the order of tolerance of selected pest species and life stages to $\mathrm{EF}$ treatments and determine the impacts of insecticidal concentrations of EF to apple quality. The long term goal is to develop EF for use in conjunction with other postharvest risk mitigation measures (e.g. high pressure washing) to reduce pest incidence to acceptable rates for export markets.

\section{METHODS}

Pest efficacy and fruit quality trials were conducted at Plant \& Food Research (PFR), Mt Albert, Auckland, between February 2013 and August 2013.

\section{Pest supply and establishment}

Obscure mealybugs (Pseudococcus viburni) were reared on sprouting potatoes at PFR Auckland. Obscure mealybug infested potatoes were collected from the colony and placed into ventilated containers with mesh bases and lids. Each container contained an estimated 50 individuals of each life stage on one to two potatoes prior to treatment. Onion thrips, Thrips tabaci, were reared on sections of leek at PFR Auckland. Leek pieces with onion thrips were collected from the colony and placed into ventilated containers. Each container had an estimated 30 individuals of each life stage. Latania scale insects (Hemiberlesia lataniae) were reared on red potatoes and butternut squash at PFR Auckland. Latania scale infested potatoes were collected from the colony and placed into ventilated containers. Each container had an estimated 50 individuals of each life stage on one to two potatoes prior to treatment. Apple leafcurling midge (ALCM, Dasineura mali) larvae were collected from infested apple leaves in early December 2012. Leaves were placed in boxes lined with tissue paper and placed into low temperature/light conditions to induce diapause (an overwintering state). Larvae that moved into the tissue paper and spun a cocoon were collected. Fifty of these diapausing larvae were placed in each container. San Jose scale (Quadraspidiotus perniciosus) on naturally infested apples were collected from the PFR orchard in Hawke's Bay in early February 2013. Ten apples, with varying levels of infestation, were placed within a fine mesh bag for treatment. Due to difficulty sourcing infested fruit, San Jose scale was treated only during the preliminary trial.

\section{Pest treatment apparatus}

The treatments were carried out in the Volatile Treatment Facility (VTF) at PFR Auckland. Fourteen identical 76.8-litre steel, gas tight chambers were used for this trial in a controlled temperature room. Insects within ventilated plastic containers were treated within metal baskets held within each of the chambers. The amount of EF and $\mathrm{CO}_{2}$ delivered to each chamber was controlled by the user input into the computer program. A $\mathrm{CO}_{2}$ gas stream (10 litres/min) was passed through a heated bead bath $\left(75^{\circ} \mathrm{C}\right)$ and liquid EF was delivered using a micro-dispenser into the heated gas stream. The gas was again passed through the heated bead bath to volatilise the EF before delivery to the chamber. The chambers filled automatically one after the other and were purged of EF once the treatment time was completed. EF was monitored in each chamber with $50 \mu \mathrm{l}$ samples taken from the chamber and injected into a gas chromatograph unit.

A preliminary trial was carried out to determine the appropriate concentrations and treatment times for $\mathrm{EF}\left(+\mathrm{CO}_{2}\right)$ to kill selected pest species and life stages at $20^{\circ} \mathrm{C}$. Obscure mealybugs, onion thrips, latania scale, San Jose scale and diapausing ALCM larvae were exposed to $\mathrm{EF}+\mathrm{CO}_{2}$ (mimicking Vapormate $^{\mathrm{TM}}$ ) at a calculated target concentration of $0.00,0.06,0.16,0.32,0.65,1.3$ or $1.95 \% \mathrm{EF}$ for 1 or $3 \mathrm{~h}$ at $20^{\circ} \mathrm{C}$. Actual measured EF concentrations were $0,0.03,0.12,0.3,0.62,1.25$ and $1.82 \%$, respectively, and corresponding $\mathrm{CO}_{2}$ 
concentrations were 21.8, 0.53, 1.18, 4.05, 8.15, 16.3 and $22.75 \%$ respectively.

Based on the results of the preliminary trial, obscure mealybugs, onion thrips and latania scale were susceptible to $\mathrm{EF}+\mathrm{CO}_{2}$; therefore, in the replicated main trial these pests were exposed to $\mathrm{EF}+\mathrm{CO} 2$ (mimicking Vapormate ${ }^{\mathrm{TM}}$ ) at calculated target concentrations of $0,0.1,0.2,0.3,0.6,1.2$ or $1.7 \% \mathrm{EF}$ for $1 \mathrm{~h}$ at $20^{\circ} \mathrm{C}$. Actual measured EF concentrations were $0,0.07,0.17,0.23,0.47,0.94$ and $1.23 \%$, respectively and corresponding $\mathrm{CO}_{2}$ concentrations were 13.56, 1.12, 1.88, 2.88, 5.47, 11.11 and $15.21 \%$, respectively. In the preliminary trial diapausing ALCM larvae were tolerant to $\mathrm{EF}+\mathrm{CO}_{2}$. Therefore in the replicated trial ALCM were exposed to a calculated target concentration of $0.0,1.0,1.5,2.0,2.5,3.0$ or $3.5 \%$ for $4 \mathrm{~h}$ at $20^{\circ} \mathrm{C}$. Actual measured EF concentrations were $0,1.25,1.85,2.24,2.50,3.39$ and $3.73 \%$ and corresponding $\mathrm{CO}_{2}$ concentrations were 25.25, $11.03,15.04,18.75,22.05,23.37$ and $25.56 \%$, respectively. Results from these treatments were compared with an untreated control, which remained at $20^{\circ} \mathrm{C}$ throughout the treatments. Four replicates of each treatment and control were carried out in the main trial.

\section{Pest assessment after treatment}

After treatment the insects were maintained at $20^{\circ} \mathrm{C}$ until assessment. Onion thrips were assessed the day after treatment. Obscure mealybug was assessed 2 days after treatment, and both scale species and ALCM were assessed 6-7 days after treatment. For all species, excluding scale, insects were assessed as live if movement was seen when gently prodded with forceps. If no movement was seen, the insect was assessed as dead. Scale insects were assessed by removal of the armoured cap and visual assessment of the body. A scale with a full, turgid body of normal colour was assessed as live and those with flaccid, dried and/or discoloured bodies were assessed as dead.

\section{Pest mortality statistical analysis}

For mortality response figures (Figures 1-4), non-parametric loess fits (Cleveland et al. 1992) were calculated and plotted on an arcsine transformed scale (e.g. transform percentage $\mathrm{p}$ by $\arcsin [\operatorname{sqrt}(\mathrm{p} / 100)])$ in $\mathrm{R}(\mathrm{R}$ Core Team). For each insect life stage, smooth lines were drawn through the percentage mortality points after exposure to $\mathrm{EF}+\mathrm{CO}_{2}$, at each treatment concentration. The error bars represent the root-mean-square of the errors of the fit for each line and are applicable over the entire mortality range on the arcsine scale.

Concentration mortality data for each replicate were fitted using the generalised linear model (Dobson 1990) capability of $\mathrm{R}$ with the complementary log-log (clog-log) link (Preisler \& Robertson 1989) and the actual EF concentration as the explanatory variable. Specifically, the assumed form of response was $\log (-\log (1-p))$ $=\mathrm{a}+\mathrm{bC}$, where $p=$ expected mortality, and $\mathrm{C}=$ concentration of EF. The coefficients from the models were used to derive the estimated lethal concentration $\left(\mathrm{g} / \mathrm{m}^{3}\right)$ to achieve $99 \%$ mortality $\left(\mathrm{LC}_{99}\right)$, the concentration to achieve a mortality of $\mathrm{cm}+(1-\mathrm{cm}) \times 0.99$, where $\mathrm{cm}$ was the control mortality. Two possible sources of extraneous mortality were considered: handling and treatment with $\mathrm{CO}_{2}$. The mortality attributed to those sources was compared using a simpler binomial GLM and found not to be significantly different. Consequently, the handling control and treatment control mortality data were combined and used as the control mortality $\mathrm{cm}$. For each life stage, a geometric mean LC and its associated standard error (SEM) were estimated, from which a 95\% confidence interval (CI) was calculated. Non-overlap of the $95 \%$ CIs is approximately equal to a test for difference at $\mathrm{P}=0.01$.

\section{RESULTS}

The preliminary trial indicated that diapausing ALCM was the most tolerant species/life stage to EF, with only 13-36\% mortality being achieved after a 3-h exposure to the concentrations tested (0.04-1.75\% EF). Onion thrips, obscure mealybug, latania scale and San Jose scale were more susceptible and required 1-h exposure to lower concentrations to achieve high mortalities (data not presented). High control mortality was observed for some species/life stages, i.e. $1^{\text {st }}$ instar latania scale and diapausing apple leafcurling midge. This was expected as these life stages have high natural mortality rates.

In the replicated trial onion thrips and latania scale were most susceptible to EF with calculated mean $\mathrm{LC}_{99} \mathrm{~s}$ for a 1 -h exposure being between 0.15 and $0.30 \% \mathrm{EF}\left(+\mathrm{CO}_{2}\right.$ ) (Figures 1 \& 2, 
Table 1). There were no significant differences between mean $\mathrm{LC}_{99} \mathrm{~s}$ for the different life stages of onion thrips and latania scale tested.

The calculated mean $\mathrm{LC}_{99} \mathrm{~s}$ for obscure mealybug life stages for a 1-h exposure was between 0.42 and $0.81 \% \mathrm{EF}\left(+\mathrm{CO}_{2}\right)$. Third instars and mature females tended to be more tolerate to EF fumigation than first or second instars (Figure 3, Table 1). However, the 95\% confidence intervals of the $\mathrm{LC}_{99}$ means did overlap (Table 1), indicating that there were no significant differences between the obscure mealybug life stages tested.

Diapausing ALCM larvae were the most tolerant species/life stage to EF. An estimated concentration of $4.94 \% \mathrm{EF}$ and exposure time of $4 \mathrm{~h}$ was required to kill $99 \%$ of diapausing ALCM (Figure 4, Table 1).

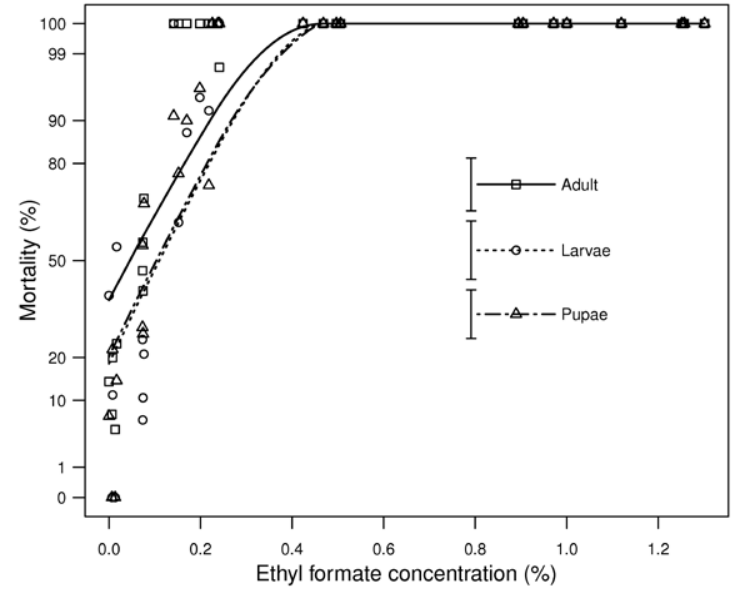

Figure 1 Percentage mortality of onion thrips after fumigation exposed to measured concentrations of ethyl formate $(\mathrm{EF})+\mathrm{CO}_{2}$ for $1 \mathrm{~h}$ at $20^{\circ} \mathrm{C}$. Vertical bars indicate the standard error of the fit.

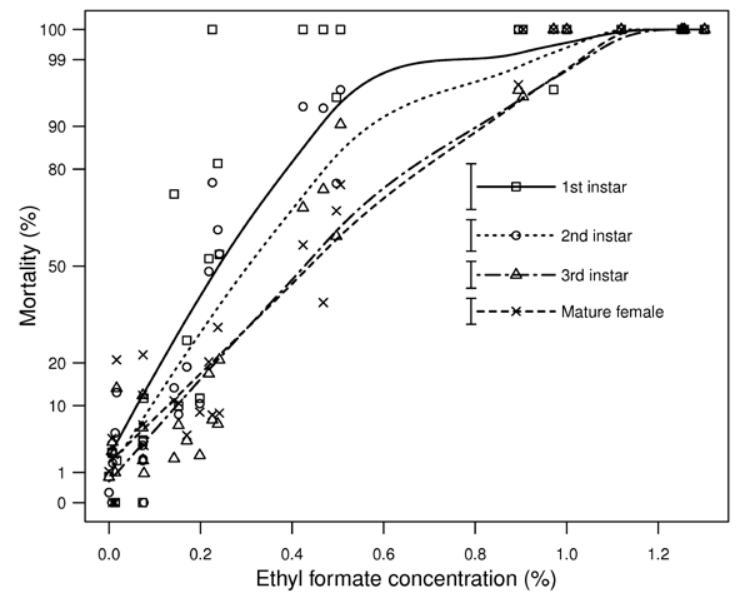

Figure 3 Percentage mortality of obscure mealybug after fumigation exposed to measured concentrations of ethyl formate $(\mathrm{EF})+\mathrm{CO}_{2}$ for $1 \mathrm{~h}$ at $20^{\circ} \mathrm{C}$. Vertical bars indicate the standard error of the fit.

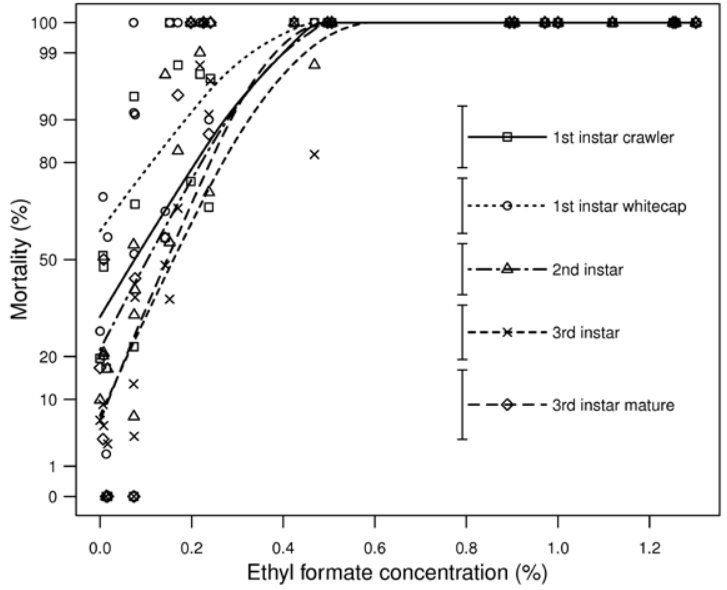

Figure 2 Percentage mortality of latania scale after fumigation exposed to measured concentrations of ethyl formate $(\mathrm{EF})+\mathrm{CO}_{2}$ for $1 \mathrm{~h}$ at $20^{\circ} \mathrm{C}$. Vertical bars indicate the standard error of the fit.

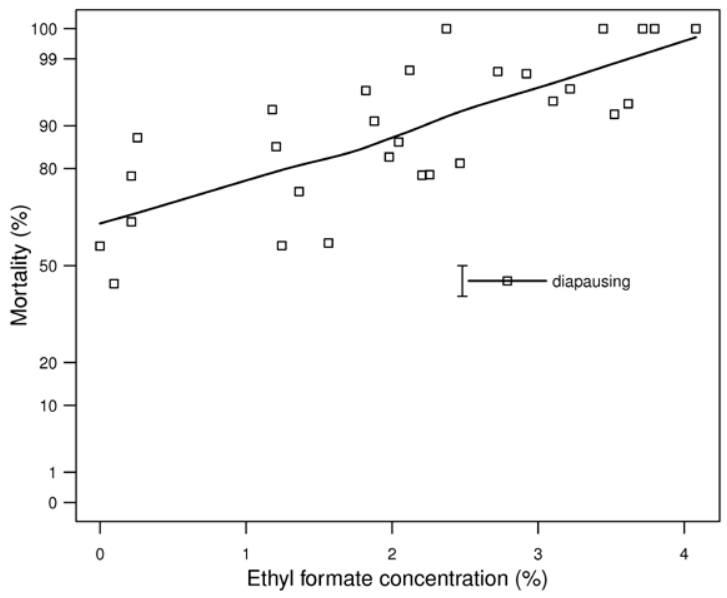

Figure 4 Percentage mortality of apple leat curling midge larvae after fumigation exposed to measured concentrations of ethyl formate (EF) $+\mathrm{CO}_{2}$ for $4 \mathrm{~h}$ at $20^{\circ} \mathrm{C}$. Vertical bars indicate the standard error of the fit. 
Table 1 Estimated lethal concentration (\%) of ethyl formate $\left(+\mathrm{CO}_{2}\right)$ required for $99 \%$ mortality $\left(\mathrm{LC}_{99}\right)$ of onion thrips, latania scale and obscure mealybug for a 1-h exposure and of apple leafcurling midge for a 4-h exposure.

\begin{tabular}{llcccc}
\hline Pest (treatment time) & Life stage & Mean & $95 \%$ CI & SEM & $\mathrm{n}$ \\
\hline Onion thrips $(1 \mathrm{~h})$ & Larva & 0.22 & $0.15-0.32$ & 0.0175 & 1160 \\
& Pupa & 0.22 & $0.15-0.32$ & 0.0198 & 530 \\
& Adult & 0.15 & $0.10-0.22$ & 0.0189 & 1160 \\
\hline Latania scale $(1 \mathrm{~h})$ & 1st instar crawler & 0.28 & $0.19-0.42$ & 0.0728 & 3184 \\
& 1st instar whitecap & 0.21 & $0.14-0.32$ & 0.0775 & 2445 \\
& 2nd instar & 0.30 & $0.20-0.44$ & 0.0574 & 3201 \\
& 3rd instar immature & 0.30 & $0.21-0.44$ & 0.0602 & 3197 \\
\hline Obscure mealybug $(1 \mathrm{~h})$ & 1st instar & 0.42 & $0.29-0.62$ & 0.1420 & 1740 \\
& 2nd instar & 0.52 & $0.36-0.77$ & 0.0462 & 2027 \\
& 3rd instar & 0.81 & $0.56-1.19$ & 0.0985 & 2649 \\
& Mature female & 0.74 & $0.51-1.09$ & 0.0643 & 2039 \\
\hline Apple leafcurling midge $(4 \mathrm{~h})$ & Diapausing larva & 4.94 & $3.38-7.22$ & 0.8073 & 1760 \\
\hline
\end{tabular}

\section{DISCUSSION}

Results from this study show that $\mathrm{EF}+\mathrm{CO}_{2}$ is a promising postharvest treatment to control thrips, scale and mealybugs on apples in New Zealand. An estimated $0.3 \% \mathrm{EF}\left(+\mathrm{CO}_{2}\right)$ treatment for $1 \mathrm{~h}$ has the potential to control $99 \%$ of onion thrips and latania scale, and $0.81 \% \mathrm{EF}\left(+\mathrm{CO}_{2}\right)$ treatment for $1 \mathrm{~h}$ has the potential to control obscure mealybug. Other studies have also shown that mealybugs, thrips and scale insects are susceptible to $\mathrm{EF}+\mathrm{CO}_{2}$ (De Lima 2009, 2010; Chhagan et al. 2013; Griffin et al. 2013; Jamieson et al. 2013) requiring concentrations of up to $1 \% \mathrm{EF}\left(+\mathrm{CO}_{2}\right)$ for $1-4 \mathrm{~h}$ to control these pests.

In a related study (M. Punter, Plant \& Food Research, unpublished data) apple quality trials were conducted using EF treatments of 1.7 or $2.5 \% \mathrm{EF}$ for $1 \mathrm{~h}$. Although these EF concentration treatments resulted in little or no impact on most fruit quality attributes measured, a cosmetic disorder termed calyx browning was noted, which appeared to be related to EF concentration and when the EF treatment was applied.

This initial feasibility trial tested $\mathrm{EF}+\mathrm{CO}_{2}$ treatment applied at ambient temperature (label recommendations for Vapormate ${ }^{\mathrm{TM}}$ include application temperatures of $>10$ or $15^{\circ} \mathrm{C}$ ) which required the fruit to be warmed to ambient temperatures prior to EF treatment. Commercially this poses logistical problems for the management of fruit within the cool-chain (similar logistical problems to methyl bromide fumigation at $12^{\circ} \mathrm{C}$ ) unless apples are treated immediately after harvest. Manufacturers of Vapormate $^{\mathrm{TM}}$ claim that these application temperatures ensure that the targeted pests are active, and therefore the treatment is more effective (B. Hamilton, BOC gases, personal communication). Previous research has shown that $\mathrm{EF}$ does have the potential to be used as a disinfestation treatment applied at $0.5^{\circ} \mathrm{C}$ (De Lima 2009, 2010; Jamieson et al. 2013).

Diapausing apple leafcurling midge were very tolerant to $\mathrm{EF}+\mathrm{CO}_{2}$, requiring an estimated 5\% $\mathrm{EF}$ for $4 \mathrm{~h}$ to control this pest. This is most likely due to the protection provided by the cocoon, inhibiting insecticidal concentrations of $\mathrm{EF}$ coming in contact with the diapausing larva. A high concentration of $3.5 \% \mathrm{EF}\left(+\mathrm{CO}_{2}\right)$ for a 4 -h exposure has been tested on 'Royal Gala' apples (M. Punter, Plant \& Food Research, unpublished data), but this caused significant skin browning and was beyond the fruit quality tolerance level. Although EF is effective against many surface pests, such as thrips, mealybugs, mites and scale insects, it is less effective against other protected pests, such as internally located codling moth (Jamieson et al. 2013) and fruit fly larvae (C. De Lima, Department of Agriculture 
and Food, Western Australia, personal communication). $\mathrm{EF}+\mathrm{CO}_{2}$ will probably not be a viable disinfestation treatment targeting diapausing ALCM or internally located codling moth larvae, and other disinfestation strategies such as heat, UV-C, HPW or pest/damage detection along with robust field control strategies will be required to target these pests.

Further research is required to examine fruit quality responses at a pesticidal range of EF concentrations, such as $0.5 \%$ (targeting thrips), $1 \%$ (targeting scale) and $1.5 \%$ (targeting mealybugs), as well as $2 \%$ to determine a potential upper limit of apple tolerance, all applied for 1, 2 or $3 \mathrm{~h}$. A related trial (H. Krishna, KC \& Associates, unpublished data) found that EF concentrations reduced by $64-71 \%$ over $2 \mathrm{~h}$ when testing fruit sorption of $1-4 \% \mathrm{EF}$ (together with $9-36 \% \mathrm{CO}_{2}$ ) applied on a single box scale (including box and cardboard fibre apple trays). Therefore to allow for fruit sorption EF concentrations should be maintained at a set level to control target pests with good air circulation. Further research is also required to determine the dose mortality response of other apple pests to $\mathrm{EF}\left(+\mathrm{CO}_{2}\right)$ treatment (e.g. mites, leafrollers, woolly apple aphid, other species of mealybugs, thrips and scale insects that cause market access issues). It would also be prudent to determine the EF sorption characteristics of semi-commercial volumes of apples and investigate the effect of treatment temperatures (e.g. $0.5,5,10^{\circ} \mathrm{C}$ ) on $\mathrm{EF}$ efficacy against pests and fruit tolerances.

\section{ACKNOWLEDGEMENTS}

The authors gratefully acknowledge Pipfruit New Zealand and the Ministry of Business, Innovation and Employment (C06X0709) for funding this research, Graeme Clare (Plant \& Food Research, Mt Albert) for rearing and providing apple leafcurling midge larvae and Vicky Davis for assistance with rearing latania scale. Also, thanks to Matt Punter, David Billing and Allan Woolf for conducting corresponding apple quality trials.

\section{REFERENCES}

Anonymous 1993. Code of federal regulations, food and drugs. Office of the Federal Register National Archives and Records Administration, Washingon DC, USA. Pp. 170-199.

Chhagan A, Jamieson LE, Griffin MJ, PageWeir NEM, Poulton J, Zulhendri F, Feng R, Connolly PG, Davis VA, Olsson S, Redpath SP, Kean AM, Woolf AB 2013. Postharvest management of New Zealand flower thrips (Thrips obscuratus) on apricots using ethyl formate or pyrethrum-based treatments. New Zealand Plant Protection 66: 63-74.

Cleveland WS, Grosse E, Shyu WM 1992. Local regression models. Chapter 8 . In: Chambers JM, Hastie TJ ed. Statistical Models in S. Wadsworth \& Brooks/Cole, CA, USA. Pp. 309-376.

De Lima C 2009. Fumigation of table grapes using ethyl formate + carbon dioxide as a quarantine treatment. Department of Agriculture and Food, Western Australia. 53 p.

De Lima C 2010. Fumigation trials of citrus using ethyl formate + carbon dioxide as a quaranitine treatment. Department of Agiculture and Food, Western Australia. 34 p.

Dobson AJ 1990. An Introduction to Generalized Linear Models. Chapman and Hall, London, UK.

Griffin MJ, Jamieson LE, Chhagan A, PageWeir NEM., Poulton J, Davis VA, Zulhendri F Connolly PG 2013. The potential of ethyl formate + carbon dioxide to control a range of horticultural pests. New Zealand Plant Protection 66: 54-62.

Jamieson LE, Page-Weir NEM, Chhagan A, Connolly PG, Poulton J, Kean AM 2013. The potential of using low oxygen and ethyl formate or ethyl acetate to disinfest fresh fruit in storage. New Zealand Plant Protection 66: 45-53.

MPI 2013. New Zealand (Maximum Residue Limits of Agricultural Compounds) Food Standards 2013. http://www.foodsafety. govt.nz/elibrary/industry/mrl-agriculturalcompounds-amdt-2013.pdf (accessed 15 April 2014). 
Preisler HK, Robertson JL 1989. Analysis of timedose-mortality data. Journal of Economic Entomology 82: 1534-1542.

Pupin F, Bikoba V, Biasi WB, Pedroso GM, Ouyang Y, Grafton-Cardwell EE, Mitcham EJ 2013. Postharvest control of western flower thrips (Thysanoptera: Thripidae) and California red scale (Hemiptera: Diaspididae) with ethyl formate and its impact on citrus fruit quality. Journal of Economic Entomology 106 (6):2341-2348.

R Core Team 2013. R:A language and environment for statistical computing. R Foundation for Statistical Computing, Vienna, Austria. ISBN 3-900051-07-0, URL http://www.R-project. org/.

Simpson T, Bikoba V, Mitcham EJ 2004. Effects of ethyl formate on fruit quality and target pest mortality for harvested strawberries. Postharvest Biology and Technology 34(3): 313-319.
Simpson T, Bikoba V, Tipping C, Mitcham EJ 2007. Ethyl formate as a postharvest fumigant for selected pests of table grapes. Journal of Economic Entomology 100(4): 1084-1090.

US FDA 2006. GRAS Substances (SCOGS) Database. http://www.fda.gov/Food/FoodIngredientsPackaging/GenerallyRecognizedasSafeGRAS/GRASSubstancesSCOGSDatabase/default.htm (accessed 20 April 2013).

US FDA 2011. Everything Added to Food in the United States (EAFUS). http://www.fda.gov/ food/foodingredientspackaging/ucm115326. htm (accessed 20 April 2013).

van Epenhuijsen CW, Hedderley DI, Somerfield KG, Brash DW 2007. Efficacy of ethyl formate and ethyl acetate for the control of onion thrips (Thrips tabaci). Journal of Crop and Horticultural Science 35: 267-274. 